\title{
Associations between serum bilirubin levels and essential trace elements status in an adult population
}

\author{
You-Fan Peng ${ }^{1}$ and Ye-Sheng Wei $^{1}$ \\ ${ }^{1}$ Department of Laboratory Medicine, Affiliated Hospital of Youjiang Medical University for Nationalities, Baise City, China \\ Correspondence to: Ye-Sheng Wei, email: yeshengwei_100@sina.com \\ Keywords: serum bilirubin, serum iron, serum copper, serum zinc \\ Received: October 07, 2016 Accepted: May 22, $2017 \quad$ Published: June 02, 2017 \\ Copyright: Peng et al. This is an open-access article distributed under the terms of the Creative Commons Attribution License 3.0 (CC BY 3.0), \\ which permits unrestricted use, distribution, and reproduction in any medium, provided the original author and source are credited.
}

\section{ABSTRACT}

Objective: This paper aims to evaluate the relations between serum bilirubin and essential trace elements in an adult population.

Results: Demographic and clinical data were stratified according to the median of serum bilirubin concentrations (50th percentiles). There were statistical differences in regarding with age, body mass index, white blood count, hemoglobin, mean corpuscular hemoglobin, alanine aminotransferase, creatinine, high-sensitivity C-reactive protein, iron, zinc and copper. Studying the correlation of serum bilirubin levels with iron, zinc, copper and high-sensitivity C-reactive protein, we found positive correlations for iron and zinc, and negative correlations for high-sensitivity C-reactive protein and copper in whole participants. Similar results of correlation analysis were repeated when the further analyses were performed separately for subjects with high and low serum bilirubin concentrations. Similar results were also observed in gender-based stratified analysis. Multiple linear regression analysis revealed that serum bilirubin levels were independently correlated with serum iron, zinc and copper.

Materials and Methods: The cross-sectional study involved 264 healthy subjects.

Conclusions: The current study demonstrated that serum bilirubin within the reference range is correlated with iron, zinc and copper in an adult population, regardless of potential confounders.

\section{INTRODUCTION}

Iron, copper and zinc are essential trace elements in human body [1]. Previous studies showed that inflammation was a main factor to induce changes in zinc, iron and copper concentrations [2-3]. Indeed, low serum levels of iron have been found to be negative correlated with some traditional inflammatory markers such as highsensitivity C-reactive protein (hs-CRP), tumor necrosis factor (TNF) and adiponectin [4], and inflammatory cytokines can decrease serum iron concentrations with no evidence of iron deficiency [5]. There was an association between serum zinc and inflammation in community population [6]. Tsuboi et al. [7] have suggested that serum zinc was correlated with higher hs-CRP in elderly women. Growing evidences have indicated that serum copper is related to inflammation in hospitalized patients and healthy volunteers [8-9]. Obviously, serum iron, copper and zinc levels may be associated with low-grade inflammatory conditions in human body [10].

Up to now, some serological indices such as serum bilirubin have been focused on diseases associated with inflammation. As the end product of heme catabolism in the systemic circulation, bilirubin has anti-inflammatory and anti-oxidative properties in vitro and in vivo [11]. In fact, bilirubin has more powerful antioxidant features than other antioxidants such as catalase, tocophero and superoxide dismutase [11]. In the clinical laboratory, a negative correlation between serum bilirubin and C-reactive protein (CRP) has been suggested by Lippi $\mathrm{G}$ et al. [12]. Lower serum bilirubin levels have been demonstrated in patients with monoxide poisoning, pulmonary embolism and chronic kidney disease [13-15], which indicates the possible relationship of 
serum bilirubin with inflammation and oxidative stress. Unfortunately, the inflammation and oxidative stress may have effect on essential trace elements metabolism, even in healthy subjects, and no study has analyzed the associations of serum bilirubin concentrations with trace elements in healthy individuals. Thus, this paper aims to evaluate the relations between serum bilirubin and iron, copper and zinc in adult population.

\section{RESULTS}

\section{Baseline characteristics}

Demographic and clinical data were stratified according to the median of serum bilirubin concentrations (50th percentiles), the median was $11.6 \mu \mathrm{mol} / \mathrm{L}$ for serum bilirubin levels. Table 1 summarizes the demographic and clinical features of the two groups. Subjects with high serum bilirubin levels had higher age, hemoglobin, $\mathrm{MCH}$, ALT, Cr, iron, zinc values than subjects with low serum bilirubin concentrations. In contrast, body mass index, WBC, copper and hs-CRP decreased from the low to the high serum bilirubin concentrations. Other variables were not different between the two groups.

\section{The correlation analysis between serum bilirubin and trace elements}

Serum bilirubin was found to be positive correlated with age, hemoglobin, $\mathrm{MCH}, \mathrm{MCHC}$, ALT and $\mathrm{Cr}$, and negative correlated with body mass index, WBC and hs-CRP in all participants. Studying the correlation of serum bilirubin levels with iron, zinc and copper, we found positive correlations for iron and zinc, and negative correlation for copper in whole participants. Similar results were also observed in gender-based stratified analysis. The further analyses were performed separately for individuals with high and low serum bilirubin concentrations. The correlation analysis showed that serum bilirubin was positive correlated with iron and zinc, and was negative correlated with hs-CRP and copper in subjects with high serum bilirubin levels, similarly, serum bilirubin was positive correlated with age, hemoglobin, $\mathrm{MCH}, \mathrm{MCHC}$, ALT, Cr, iron and zinc, and was negative correlated with hs-CRP and copper in subjects with low serum bilirubin levels, as shown in Table 2.

\section{Serum bilirubin and trace elements in multiple linear regression analysis}

Multiple linear regression analysis revealed that serum bilirubin levels were independently correlated with serum iron, zinc and copper (beta $=0.276$, $P<0.001$; beta $=0.312, P<0.001$; beta $=-0.304$, $P<0.001$ ), when gender, age, body mass index, WBC, hemoglobin, $\mathrm{MCH}, \mathrm{ALT}, \mathrm{AST}, \mathrm{Cr}$, hs-CRP, iron, zinc and cooper were considered as independent variables, and serum bilirubin were served as dependent variables in multiple linear regression analysis (Table 3).

\section{DISCUSSION}

As far as we know, this is the first study to investigate the associations between serum bilirubin and essential trace elements in an adult population. The major findings of the current study are that serum bilirubin is positive correlated with iron and zinc, and negative correlated with copper in an adult population, further, serum bilirubin is independently correlated with serum iron, zinc and copper in multiple linear regression analysis.

Serum bilirubin has been used as an outstanding diagnostic marker in liver diseases such as acute hepatitis, liver cirrhosis and autoimmune hepatitis [16]. Previous clinical studies have demonstrated that serum bilirubin concentrations are related with chronic obstructive pulmonary disease, migraine and cancer [17-19]. Kawamoto et al. [20] found that serum bilirubin was useful as an underlying risk marker for kidney function. Moreover, a reverse relationship between serum bilirubin and carotid atherosclerosis has been suggested in elderly population [21], and serum bilirubin concentrations are correlated with disease activity in patients with rheumatoid arthritis and polymyositis [22-23]. In other oxidative stress-mediated diseases, lower serum bilirubin levels have been also reported to be inverse associated with Takayasu Arteritis, coronary atherosclerosis and myocardial infarction [24-26].The present results found that the physiological serum bilirubin levels were tightly correlated with essential trace elements such as iron, zinc and copper in an adult population. Although the mechanisms in regarding with the correlations between serum bilirubin and these trace elements have not been clear, however, inflammation may be a bridge to explain the relations in the study population.

Inflammation has an important effect on nutrient status, particularly for essential trace elements [27]. Some studies found the associations between CRP and serum iron, zinc and copper [28-29]. There is evidence that zinc presents strong anti-oxidative and antiinflammatory features [30]. Serum zinc concentrations have been found to be correlated with inflammatory markers, including interleukin-6 (IL-6), TNF, and CRP, and serum zinc decreased these inflammatory cytokines by the downregulation of NF-kB activation [31-32]. In addition, low serum zinc and high serum copper concentrations have been demonstrated to be associated with inflammatory factors in patients with cardiovascular disease [33]. Further, copper has been regarded as an inflammatory biomarker with synthesis and secretion during inflammation [34]. Inflammation has also important impact on iron metabolism [5]. In conclusion, inflammation may increase serum copper concentrations, whilst decrease serum zinc and iron 
Table 1: Baseline characteristics of all subjects according to the median of serum bilirubin concentrations (50th percentiles)

\begin{tabular}{llll}
\hline & \multicolumn{1}{c}{$\leq \mathbf{1 1 . 6}$} & \multicolumn{1}{c}{$\mathbf{1 1 . 6}$} & \\
\cline { 2 - 4 } & \multicolumn{1}{l}{$\boldsymbol{N}=\mathbf{1 2 9}$} & $\mathbf{N}=\mathbf{1 3 5}$ & $\boldsymbol{P}$-value \\
\hline Gender $(\mathrm{F} / \mathrm{M})$ & $57 / 72$ & $62 / 73$ & 0.776 \\
Age $(\mathrm{yr})$ & $28.4 \pm 18.75$ & $41.2 \pm 15.58$ & $<0.001$ \\
Body mass index $\left(\mathrm{kg} / \mathrm{m}^{2}\right)$ & $23.4 \pm 2.42$ & $22.8 \pm 2.63$ & 0.029 \\
White blood count $\left(10^{9} / \mathrm{L}\right)$ & $6.7 \pm 1.44$ & $6.3 \pm 1.47$ & 0.016 \\
Hemoglobin $(\mathrm{g} / \mathrm{L})$ & $128.8 \pm 12.80$ & $134.3 \pm 12.31$ & $<0.001$ \\
Mean corpuscular hemoglobin $(\mathrm{pg})$ & $27.2 \pm 2.98$ & $28.5 \pm 3.07$ & $<0.001$ \\
Mean corpuscular hemoglobin concentration $(\mathrm{g} / \mathrm{L})$ & $326.5 \pm 10.64$ & $326.8 \pm 27.54$ & 0.902 \\
Alanine aminotransferase $(\mathrm{U} / \mathrm{L})$ & $17.5 \pm 8.86$ & $19.6 \pm 8.40$ & 0.047 \\
Aspartate aminotransferase $(\mathrm{U} / \mathrm{L})$ & $22.3 \pm 6.20$ & $21.9 \pm 5.54$ & 0.669 \\
Creatinine $(\mathrm{umol} / \mathrm{L})$ & $58.1 \pm 17.60$ & $70.1 \pm 12.94$ & $<0.001$ \\
Albumin $(\mathrm{g} / \mathrm{L})$ & $44.7 \pm 3.53$ & $44.6 \pm 3.26$ & 0.850 \\
Globulin $(\mathrm{g} / \mathrm{L})$ & $22.1 \pm 4.09$ & $22.8 \pm 3.84$ & 0.180 \\
High-sensitivity C-reactive protein $(\mathrm{mg} / \mathrm{L})$ & $1.4 \pm 1.03$ & $1.0 \pm 0.90$ & 0.002 \\
Serum iron $(\mu \mathrm{mol} / \mathrm{L})$ & $11.9 \pm 1.88$ & $15.7 \pm 5.64$ & $<0.001$ \\
Serum copper $(\mu \mathrm{mol} / \mathrm{L})$ & $12.7 \pm 4.51$ & $10.0 \pm 3.22$ & $<0.001$ \\
Serum zinc $(\mu \mathrm{mol} / \mathrm{L})$ & $10.9 \pm 1.88$ & $12.0 \pm 2.64$ & $<0.001$ \\
\hline
\end{tabular}

levels, even in healthy subjects. Bilirubin is a powerful endogenous anti-oxidant that scavenges peroxyl radicals and inhibits oxidative stress, and bilirubin has antiinflammatory and anti-oxidative and immunosuppressive characteristics [35]. It is suggested that serum bilirubin concentrations are directly correlated with serum antioxidant capacity [36]. Importantly, bilirubin has been reported to be a protector in inflammatory processes in vasculature [37]. We speculate that serum bilirubin may be destroyed and consumed against inflammation in human body. Interesting, in agree with the possibility, a reverse correlation between serum bilirubin and hs-CRP was observed in our study. Therefore, the relations of serum bilirubin with iron, zinc and copper should be attributed to systemic low-grade inflammation. On the other hand, in serum, copper and iron are mostly bound to ceruloplasmin and transferrin respectively, and zinc is bound to albumin and a-macroglobulin. In fact, these proteins related with trace elements are associated with acute phase proteins (APPs), and CRP is positive correlated with APPs. Thus, the elevation of the bilirubin levels is related with low serum CRP levels due to its anti-inflammatory response. In a healthy population, relatively high levels of bilirubin are related with low CRP levels, so that it can explain the correlation observed with the copper, iron and zinc levels under this condition.

Several limitations should be acknowledged. First, our study was limited by a small sample, resulting in a low statistical power. Second, the information on food intake was not available, which may have an effect on serum iron, copper and zinc in this cross-sectional study, even though the albumin, globulin and body mass index were used as complementary data for the general nutritional status in our study. Third, we have no the physiology information in the study population, such as menstruation in females. Fourth, more accurate measurement methods for serum copper, iron and zinc were needed in the present study. Fifth, because the study only included healthy subjects, the extrapolation of results may be limited in hospitalized patients. Finally, the detailed information on drugs and supplements was not obtained in all subjects, which may contain trace elements. The current study demonstrated that serum bilirubin within the reference range is correlated with iron, zinc and copper concentrations in an adult population, regardless of potential confounders. However, further studies were needed in different settings with a larger sample size.

\section{MATERIALS AND METHODS}

\section{Study population}

The cross-sectional study involved 264 healthy subjects from the Affiliated Hospital of Youjiang Medical University for Nationalities between November 2015 and August 2016, and all subjects underwent laboratory and physical examinations. Our study included healthy subjects without apparent diseases. Following participants with clinical findings are ineligible: diabetes, hypertension, cardiovascular disease, dyslipidemia, renal or liver dysfunction, acute or 
Table 2: Correlations between serum bilirubin and demographic and laboratory parameters

\begin{tabular}{|c|c|c|c|c|c|c|}
\hline & \multicolumn{2}{|c|}{$\begin{array}{c}\text { All } \\
\text { subjects }\end{array}$} & \multicolumn{2}{|c|}{$\begin{array}{l}\text { Subjects with high } \\
\text { serum bilirubin }\end{array}$} & \multicolumn{2}{|c|}{$\begin{array}{l}\text { Subjects with low } \\
\text { serum bilirubin }\end{array}$} \\
\hline & $r$ & $P$-value & $r$ & $P$-value & $r$ & $P$-value \\
\hline Age & 0.377 & $<0.001$ & 0.001 & 0.992 & 0.305 & $<0.001$ \\
\hline Body mass index & -0.157 & 0.011 & -0.024 & 0.785 & -0.118 & 0.171 \\
\hline White blood count & -0.133 & 0.031 & 0.113 & 0.193 & -0.051 & 0.567 \\
\hline Hemoglobin & 0.285 & $<0.001$ & 0.082 & 0.346 & 0.230 & 0.009 \\
\hline Mean corpuscular hemoglobin & 0.350 & $<0.001$ & 0.038 & 0.662 & 0.314 & $<0.001$ \\
\hline Mean corpuscular hemoglobin concentration & 0.171 & 0.005 & 0.064 & 0.460 & 0.207 & 0.019 \\
\hline Alanine aminotransferase & 0.215 & $<0.001$ & 0.029 & 0.741 & 0.268 & 0.002 \\
\hline Aspartate aminotransferase & 0.034 & 0.587 & 0.029 & 0.738 & 0.108 & 0.224 \\
\hline Creatinine & 0.370 & $<0.001$ & 0.067 & 0.440 & 0.218 & 0.013 \\
\hline Albumin & 0.011 & 0.865 & -0.011 & 0.906 & 0.004 & 0.961 \\
\hline Globulin & 0.087 & 0.158 & 0.083 & 0.348 & -0.002 & 0.983 \\
\hline High-sensitivity C-reactive protein & -0.311 & $<0.001$ & -0.187 & 0.030 & -0.325 & $<0.001$ \\
\hline Serum iron & 0.452 & $<0.001$ & 0.275 & 0.001 & 0.394 & $<0.001$ \\
\hline Serum copper & -0.475 & $<0.001$ & -0.266 & 0.002 & -0.485 & $<0.001$ \\
\hline Serum zinc & 0.311 & $<0.001$ & 0.180 & 0.037 & 0.335 & $<0.001$ \\
\hline
\end{tabular}

r: correlation coefficient.

Note: High corresponds to individuals with bilirubin levels higher than $11.6 \mu \mathrm{mol} / \mathrm{L}$.

Table 3: Potential factors associated with serum bilirubin in multiple linear regression

\begin{tabular}{lccccc}
\hline & \multicolumn{2}{c}{$\begin{array}{c}\text { Unstandardized } \\
\text { cofficients }\end{array}$} & $\begin{array}{c}\text { Standardized } \\
\text { cofficients }\end{array}$ & $\boldsymbol{t}$ & $\boldsymbol{P}$-value \\
\hline & B & Std Error & Beta & & \\
Age & 0.054 & 0.012 & 0.215 & 4.691 & $<0.001$ \\
Body mass index & -0.197 & 0.080 & -0.108 & -2.464 & 0.014 \\
Mean corpuscular hemoglobin & 0.148 & 0.070 & 0.099 & 2.110 & 0.036 \\
Serum iron & 0.236 & 0.041 & 0.276 & 5.816 & $<0.001$ \\
Serum copper & -0.343 & 0.053 & -0.304 & -6.517 & $<0.001$ \\
Serum zinc & 0.613 & 0.090 & 0.312 & 6.790 & $<0.001$ \\
\hline
\end{tabular}

B: regression coefficient; Std Error: standard error.

chronic infectious disease, inflammatory disease, anemia, malignant tumor, smoking, alcohol consumption, mental disorders and pregnancy. Our study was approved by the Affiliated Hospital of Youjiang Medical University for Nationalities Institutional Review Board.

\section{Clinical and laboratory variables}

Fasting venous blood was used for all participants. All laboratory indexes were measured within 2 hours. White blood count (WBC), hemoglobin, mean corpuscular hemoglobin $(\mathrm{MCH})$ and mean corpuscular hemoglobin concentration (MCHC) were measured by automated hematology analyzer (Sysmex XN2000, Japan). Serum bilirubin, alanine aminotransferase (ALT), aspartate aminotransferase (AST), creatinine (Cr), albumin(ALB), hs-CRP, iron, copper and zinc were measured by automatic biochemical analyzer (Hitachi7600, Japan). The body mass index was calculated as an individual's weight in kilograms divided by the square of height in meters.

\section{Determination of laboratory variables}

The kits of serum bilirubin, ALT, AST, Cr, ALB, hs$\mathrm{CRP}$, iron, copper and zinc were purchased from Maker 
Biotechnology co., LTD. We used oxidizing method (vanadate as oxidizing reagent), alanine substrate method, 2,4-dinitrobenzene hydrazine method, sarcosine oxidase method and bromocresol green method to measure serum bilirubin, ALT, AST, Cr, ALB levels, respectively. The serum concentrations of hs-CRP were measured by immunoturbidimetry, and serum iron, copper and zinc were assessed by colorimetric method. All tests were performed in the identical laboratory.

\section{Statistical analysis}

Data analyses were performed by SPSS 16.0 software (SPSS Inc., Chicago, IL, USA). The normal distribution for continuous variables was tested by Kolmogorov-Smirnov test. Intergroup comparisons between the two groups were assumed by student's $t$-test, Mann-Whitney $U$ test and Chi-square test. Correlations between serum bilirubin and other variables were calculated by Spearman's test. Multiple linear regression analysis was used to identify the correlations between serum bilirubin level and iron, copper and zinc in the study population. $P<0.05$ was used as the criterion of statistical significance.

\section{Authors' contributions}

YFP conceived the study, collected data, performed data analysis and wrote the manuscript. YSW confirmed the final versions. All authors approved the final version of the manuscript.

\section{ACKNOWLEDGMENTS}

This study was supported by the National Natural Science Foundation (No. 81560552).

\section{CONFLICTS OF INTEREST}

The authors have no financial conflicts of interest.

\section{REFERENCES}

1. Lin CN, Wang LH, Shen KH. Determining urinary trace elements $(\mathrm{Cu}, \mathrm{Zn}, \mathrm{Pb}, \mathrm{As}$, and $\mathrm{Se})$ in patients with bladder cancer. J Clin Lab Anal. 2009; 23:192-195.

2. Thurnham M, Mwaniki DL, De Wagt A. Micronutrients in childhood and the influence of subclinical inflammation. Proc Nutr Soc. 2005; 64:502-9.

3. Rousham EK, Northrop-Clewes CA, Lunn PG. Maternal reports of child illness and the biochemical status of the child: the use of morbidity interviews in rural Bangladesh. Br J Nutr. 1998; 80:451-6.

4. Tsuboi A, Watanabe M, Kazumi T, Fukuo K. Association of low serum iron levels with low-grade inflammation andhyperadiponectinemia in community-living elderly women. J Atheroscler Thromb. 2013; 20:670-7.
5. Roy CN, Andrews NC. Anemia of inflammation: the hepcidin link. Curr Opin Hematol. 2005; 12:107-11.

6. Friis H, Wahed MA, Kongsbak K, Thilsted SH. Acute phase protein levels, T. trichiura, and maternal education are predictors of serum zinc in a cross-sectional study in Bangladeshi children. J Nutr. 2006; 136:2262-8.

7. Tsuboi A, Terazawa Watanabe M, Kazumi T, Fukuo K. Serum copper, zinc and risk factors for cardiovascular disease in community-living Japanese elderly women. Asia Pac J Clin Nutr. 2014; 23:239-45.

8. Ghayour-Mobarhan M, Taylor A, New SA, Lamb DJ, Ferns GA. Determinants of serum copper, zinc and selenium in healthy subjects. Ann Clin Biochem. 2005; 42:364-75.

9. Bo S, Durazzo M, Gambino R, Berutti C, Milanesio N, Caropreso A, Gentile L, Cassader M, Cavallo-Perin P, Pagano G. Associations of dietary and serum copper with inflammation, oxidative stress, and metabolic variables in adults. J Nutr. 2008; 138:305-31.

10. Bui VQ, Stein AD, DiGirolamo AM, Ramakrishnan U, Flores-Ayala RC, Ramirez-Zea M, Grant FK, Villalpando S, Martorell R. Associations between serum C-reactive protein and serum zinc, ferritin, and copper in Guatemalan schoolchildren. Biol Trace Elem Res. 2012; 148:154-60.

11. Stocker R, Yamamoto Y, McDonagh AF, Glazer AN, Ames BN. Bilirubin is an antioxidant of possible physiological importance. Science. 1987; 235:1043-6.

12. Lippi G, Targher G. Further insights on the relationship between bilirubin and C-reactive protein. Clin Chem Lab Med. 2012; 50:2229-30.

13. Cervellin G, Comelli I, Buonocore R, Picanza A, Rastelli G, Lippi G. Serum bilirubin value predicts hospital admission in carbon monoxide-poisoned patients. Active player or simple bystander? Clinics (Sao Paulo). 2015; 70:628-31.

14. Targher G, Zoppini G, Cesare Guidi G, Lippi G. Relationship between serum bilirubin and kidney function in non-diabetic and diabetic individuals. Kidney Int. 2009; 75:863.

15. Cervellin G, Buonocore R, Sanchis-Gomar F, Lippi G. Low serum bilirubin values are associated with pulmonary embolism in a case-control study. Clin Chem Lab Med. 2016; 54:e229-30.

16. Hulzebos CV, Dijk PH. Bilirubin-albumin binding, bilirubin/ albumin ratios, and free bilirubin levels: where do we stand? Semin Perinatol. 2014; 38:412-21.

17. Apperley S, Park HY, Holmes DT, Man SFP, Tashkin D, Wise RA, Connett JE, Sin DD. Serum Bilirubin and Disease Progression in Mild COPD. Chest. 2015; 148:169-75.

18. Peng YF, Xie LQ, Xiang Y, Xu GD. Serum Bilirubin and Their Association With C-Reactive Protein in Patients With Migraine. J Clin Lab Anal. 2016; 21. doi: 10.1002/ jcla.21967.

19. Song Q, Wang B, Wang S, Zhang YM, Chen WH. Lower serum levels of bilirubin in the newly diagnosed lung cancer patients: A case-control study in China. J Cancer Res Ther. 2015; 54:e229-30. 
20. Kawamoto R, Ninomiya D, Hasegawa $Y$, Kasai $Y$, Kusunoki T, Ohtsuka N, Kumasi T. Association between serum bilirubin and estimated glomerular filtration rate among elderly persons. PLoS One. 2014; 9:e115294.

21. Kawamoto R, Ninomiya D, Hasegawa Y, Kasai Y, Kusunoki T, Ohtsuka N, Kumagi T, Abe M. Mildly elevated serum bilirubin levels are negatively associated with carotid atherosclerosis among elderlypersons. PLoS One. 2015; 9:e114281.

22. Peng YF, Wang JL, Pan GG.The correlation of serum bilirubin levels with disease activity in patients with rheumatoid arthritis. Clin Chim Acta. 2017; 469:187-90.

23. Peng YF, Zhang L, Pan GG, Wei YS. A potential clinical usefulness of measuring serum bilirubin levels in patients with polymyositis. Eur Rev Med Pharmacol Sci. 2016; 20:631-5.

24. Peng YF, Deng YB. Serum Bilirubin Concentrations in Patients With Takayasu Arteritis. Arch Pathol Lab Med. 2017; 18. doi: 10.5858/arpa.2016-0362-OA.

25. Franchini M, Targher G, Lippi G. Serum bilirubin levels and cardiovascular disease risk: a Janus Bifrons? Adv Clin Chem. 2010; 50:47-63.

26. Hamur H, Duman H, Bakirci EM, Kucuksu Z, Demirelli S, Kalkan K, Degirmenci H. Bilirubin Levels and Thrombus Burden in Patients With ST-Segment Elevation Myocardial Infarction. Angiology. 2016; 67:565-70.

27. Brown KH, Lanata CF, Yuen ML, Peerson JM, Butron B, Lonnerda 1B. Potential magnitude of the misclassification of a population's trace element status due to infection: example from a survey of young Peruvian children. Am J Clin Nutr. 1993; 58:549-54.

28. Peng YF, Wang CF, Pan GG. Relation of serum $\gamma$-glutamyl transferase activity with copper in an adult population. Clin Chem Lab Med. 2017 Mar 7. doi: 10.1515/cclm-2016-0551. [Epub ahead of print].

29. Thurnham DI, McCabe LD, Haldar S, Wieringa FT, Northrop-Clewes CA, McCabe GP. Adjusting plasma ferritin concentrations to remove the effects of subclinical inflammation in the assessment of iron deficiency: a metaanalysis. Am J Clin Nutr. 2010; 92:546-55.

30. de Oliveira Otto MC, Alonso A, Lee DH, Delclos GL, Jenny NS, Jiang R, Lima JA, Symanski E, Jacobs DR Jr, Nettleton JA. Dietary micronutrient intakes are associated with markers of inflammation but not with markers of subclinical atherosclerosis. J Nutr. 2011; 141:1508-15.

31. Jung S, Kim MK, Choi BY. The Relationship between Zinc Status and Inflammat -oryMarker Levels in Rural Korean Adults Aged 40 and Older. PLoS One. 2015; 10:e0130016.

32. Bao B, Prasad AS, Beck FW, Fitzgerald JT, Snell D, Bao GW, Singh T, Cardozo LJ. Zinc decreases C-reactive protein, lipid peroxidation, and inflammatory cytokines in elderly subjects: a potential implication of zinc as an atheroprotective agent. Am J Clin Nutr. 2010; 91:1634-41.

33. Marniemi J, Järvisalo J, Toikka T, Räihä I, Ahotupa M, Sourander L. Blood vitamins, mineral elements and inflammation markers as risk factors of vascular and nonvascular disease mortality in an elderly population. Int $\mathrm{J}$ Epidemiol. 1998; 27:799-807.

34. Turgut A, Özler A, Görük NY, Tunc SY, Evliyaoglu O, Gül T. Copper, ceruloplasmin and oxidative stress in patients with advanced-stage endometriosis. Eur Rev Med Pharmacol Sci. 2013; 17:1472-78.

35. Kapitulnik J. Bilirubin: an endogenous product of heme degradation with both cytotoxic and cytoprotective properties. Mol Pharmacol. 2004; 66:773-9.

36. Vitek L. The role of bilirubin in diabetes, metabolic syndrome, and cardiovascular diseases. Front Pharmacol. 2012; 3:55-60.

37. Kawamura $\mathrm{K}$, Ishikawa $\mathrm{K}$, Wada $\mathrm{Y}$, Kimura $\mathrm{S}$, Matsumoto H, Kohro T, Itabe H, Kodama T, Maruyama Y. Bilirubin from heme oxygenase-1 attenuates vascular endothelial activation and dysfunction. Arterioscler Thromb Vasc Biol. 2005; 25:155-60. 